\title{
Influence of NAO on forming the UTCl index in Kłodzko
}

\author{
Arkadiusz Głogowski $^{1}$ (D) . Krystyna Bryśs ${ }^{1} \cdot$ Tadeusz Bryśs $^{2}$
}

Received: 5 March 2019 / Accepted: 20 July 2020 / Published online: 26 September 2020

(c) The Author(s) 2020

\begin{abstract}
The aim of this paper is to understand the role of the macrocirculation factor in shaping the dynamics of long-term bioclimatic conditions, with reference to Kłodzko in the Polish part of the Central Sudetes. The variability of bioclimatic conditions in Kłodzko for the period 1966-2017 was analysed, exposing its local specificity. The Universal Thermal Climate Index (UTCI) was taken as an indicator of the analysed bioclimatic features. The influence of the North Atlantic Oscillation (NAO) on the variability of this index and its constituent meteorological elements, e.g. air temperature, vapour pressure, wind speed, and solar conditions, was examined. On the basis of the winter NAO Hurrell coefficient, the analysed years were divided into two opposing groups representing either a negative or positive Hurrell index. A comparison between these two year-groups for the mean values of UTCI and the examined meteorological elements showed a clear intergroup difference in these values. Except for cloudiness, the importance of the macrocirculation genesis of NAO was verified by the statistically significant correlation between the Hurrell index on the one hand and the tested UTCI index and its constituent meteorological elements on the other.
\end{abstract}

\section{Introduction}

Bioclimatic conditions are used to asses climate changes, health research, epidemiology, military or urban planning in order to determine the attractiveness of tourist places. There are many indicators for determining bioclimatic conditions which de Freitas and Grigorieva (2017) aggregate to a few groups. Indicators may be based on a single parameter like the physical saturation deficit (Thilenius and Dorno 1925) or wet-bulb temperature: $T_{w b}$ (Haldane 1905) explains the meteorological processes rather than bioclimatic conditions. The second group of bioclimatic indicators comprise models (algebraic or statistical) based on more than one

Arkadiusz Głogowski

arkadiusz.glogowski@upwr.edu.pl

Krystyna Bryś

krystyna.brys@upwr.edu.pl

Tadeusz Bryś

tbrys@tlen.pl

1 Institute of Environmental Protection and Development, Wrocław University of Environmental and Life Sciences, ul. C. K. Norwida 25, 50-375 Wrocław, Poland

2 Polish Geophysical Society, Wrocław Division, pl. Grunwaldzki 24, 50-357 Wrocław, Poland parameter, namely, air enthalpy: AirE, i (Gregorczuk 1968); humidex: HD (Masterson and Richardson 1979); and wetbulb globe temperature: WBGT (Yaglou et al. 1957). They were used for bioclimatic conditions where air temperature is greater then $0{ }^{\circ} \mathrm{C}$. On the other hand, apparent temperature: AT (Arnoldy 1962) and Wind Chill Index: WCI (Siple and Passel 1945) are useful in temperatures smaller than $0{ }^{\circ} \mathrm{C}$. Other indicators calculating how our clothes insulate us from outdoor conditions, e.g. Insulation Predicted index: Iclp (Błażejczyk 2011). Finally, there are indexes in full spectrum of temperature $\left(-45\right.$ to $\left.45{ }^{\circ} \mathrm{C}\right)$ like effective temperature: ET (Missenard and Balthazard 1933) but these describe only the relations with the human body based on temperature, wind speed and water vapour pressure. Further, we can find indexes based on human heat or energy exchange depending on meteorological conditions such as physiological equivalent temperature: PET (Mayer and Höppe 1987); physiological subjective temperature: PST (Błażejczyk and Matzarakis 2007); apparent temperature: AT or heat index: HI (Steadman 1979, 1984). Revision of these indexes can be found in the works Epstein and Moran (2006), de Freitas and Grigorieva (2017), and Błażejczyk et al. (2012). The compassion of several selected bioclimatic indices in Arctic conditions was also made by Araźny et al. (2019).

Most of the aforementioned indexes cannot be used throughout the whole year and hence difficult to compare, or 
indexes only take into account a few meteorological parameters. The Universal Thermal Climate Index (UTCI) is devoid of these defects. In 2009, the World Meteorological Organi (WMO) promoted the UTCI as the most appropriate tool for determining bioclimatic conditions. Błażejczyk et al. (2012) compared the proposed index with other indices previously used in the literature by showing their mutual dependencies. The UTCI has been frequently used in bioclimatic analyses by many Polish scientists. Such analyses were conducted for Warsaw (Błażejczyk et al. 2014), for Kołobrzeg, and for Poznań and Szczawno (Okoniewska and Więcław 2013). Chabior (2011) studied the bioclimatic conditions of Szczecin, while Nidzgorska-Lencewicz and Mąkosza (2013) attempted to combine UTCI with human mortality. Idzikowska (2011) compared the bioclimatic situation in Warsaw with three other European capitals (Paris, Rome and Budapest). Against this background, research into the relationship between bioclimatic conditions and atmospheric circulation is still scarce in Poland (Bryś and Ojrzyńska 2016; Rozbicka and Rozbicki 2018).

Studies of bioclimatic conditions have also been undertaken in other countries In southern Brazil, bioclimatic conditions have been analysed by Bröde et al. (2012). In the Czech Republic, Novak (2013) examined how the UTCI values, depending on changes in individual components of the index, are applied. For the purpose of tourism, an analysis of UTCI values was performed for instance in Athens (Matzarakis and Nastos 2011), Hungary (Nemeth 2011), Luxemburg (Matzarakis et al. 2013), Tanzania (Ndetto and Matzarakis 2015), Australia (Coutts et al. 2016) and China (Ge et al. 2017). Some researchers have seen links between bioclimatic conditions and air pollution (Jacobs et al. 2014;
Ndetto and Matzarakis 2015). There are also important works investigating the dependence of human health on biometeorological conditions (Kozłowska-Szczęsna et al. 2004; Matzarakis and Endler 2010; De Freitas and Grigorieva 2014; Di Napoli et al. 2018). A characteristic feature of modern bioclimatic research is the increasingly regular use of the UTCI. The analyses made in this work are based on studies of UTCI. Variability is considered here against the background of macrocirculatory source conditions. The aim of this paper is to investigate the impact of the macrocirculatory phenomenon, i.e. the North Atlantic Oscillation (NAO), on the dynamics of long-term bioclimatic impacts on the human body in outdoor conditions of a mediumsized city in the Sudetes (Central Europe). Similar studies were conducted in Brazil in relation to the El Niño-Southern Oscillation (ENSO) and its influence on the climate of this region (Grimm et al. 1998; Kane 1997; Berlato et al. 2005). Diniz et al. (2019) shows that El Niño increases the discomfort due to the heat while La Niña causes them to decrease. Studies in this direction are important since these phenomena that are related to macrooscillation process directly affect the health of the population in the regions. This task is accomplished in the case of Klodzko located in the northeastern parts of Central Sudetes in Poland (Fig. 1).

\section{Data and methodology}

Meteorological data from 1966-2017, used in this article, were obtained from the synoptic station of the Institute of Meteorology and Water Management (IMGW 2018) (dane.imgw.pl) in Kłodzko. The data was downloaded
Fig. 1 Location of the Kłodzko synoptic station

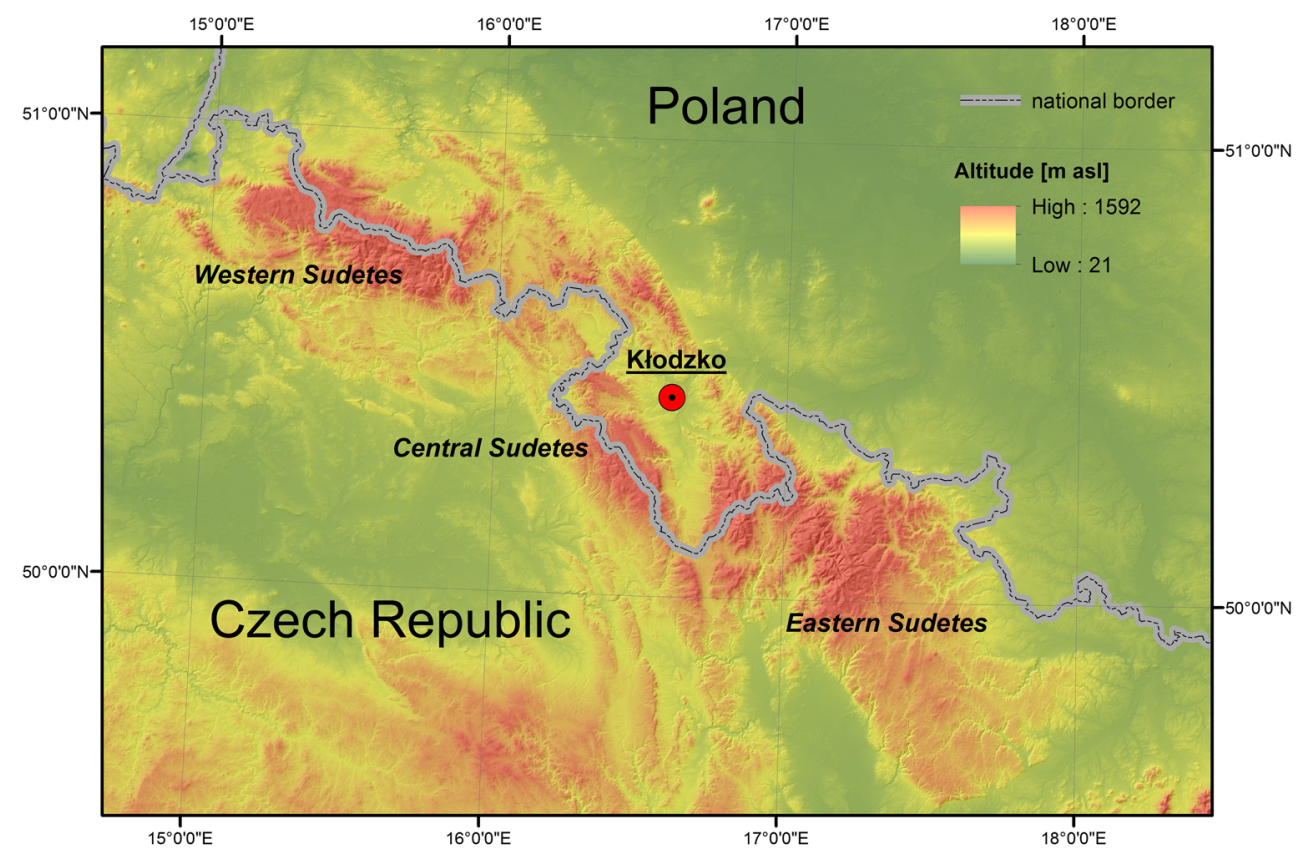


using the climate R package (Czernecki et al. 2020). This station is considered by scientists in Poland as the most important station for the whole region of the Kłodzko Basin (Kozłowska-Szczęsna et al. 2004), and it is also useful for analysing regional changes in places which do not have a fully documented measurement history. The basis for the research was provided by values of elementary meteorological elements, measured at 12 UTC, such as air temperature, water vapour pressure, air humidity, wind speed, and cloudiness. With this data, daily UTCI values were calculated. To determine the relationship between UTCI and NAO, monthly data was used. In addition, the correlation between UTCI and NAO was aggregated by years on two separate groups:

1) With the negative Hurrell index,

2) With the positive Hurrell index,

the winter NAO Hurrel DJFM (December, January, February, March) was used. The NAO Hurrel index is based on the difference between the normalised sea level pressure (SLP) between Lisbon in Portugal and Stykkisholmur in Iceland (Hurrell and Staff 2018). The values of the Hurrell NAO index from the years 1966-2017 were obtained from the National Center for Atmospheric Research (NCAR) (climatedataguide.ucar.edu). The available interval of the NAO Hurrell index was with the monthly and annual step. For further analysis, daily UTCI values were averaged for monthly and yearly means.

The synoptic station in Kłodzko $\left(16^{\circ} 36^{\prime} 51^{\prime \prime} \mathrm{E}, 50^{\circ}\right.$ $26^{\prime} 13^{\prime \prime} \mathrm{N}, h=350 \mathrm{~m}$ a.s.l.) is located in the western part of the city in its agricultural periphery. The station is located about $50-100 \mathrm{~m}$ southwards from the national road No. 8 (section E67), with meadows and arable land on its stretch. Kłodzko (Fig. 1) is an attractive tourist town with a population of 27,000 , stretched out over an area of about $25 \mathrm{~km}^{2}$. The town is the starting point of the nearby mountain ridges. It is located on the Nysa Klodzka River (tributary to the Oder) in the northern part of the Kłodzko Basin at an altitude of 280 - $401 \mathrm{~m}$ a.s.l. and is an important communication junction. It is also located near several spa health resorts, including Lądek Zdrój, Polanica Zdrój and Duszniki Zdrój. The peripheral location of the synoptic station means that it does not fully represent the bioclimatic features of the Kłodzko urban environment. However, as a reference station, it serves as a reliable reference for the current analysis, which is intended to be the basis for future, detailed studies of the bioclimatic diversity of different areas of the city, as well as the bioclimate of the Kłodzko region.

\subsection{Universal Thermal Climate Index}

The Universal Thermal Climate Index (UTCI) is based on Fiala's multi-node thermoregulation model (Fiala et al.
1999, 2001), which was integrated along with the advanced human clothing model (Havenith et al. 2012). It makes it possible to determine the influence of air temperature on the insulating capacity of human clothing. The UTCI is defined as the equivalent of air temperature wherein the basic physiological parameters of the body under the reference conditions assume the same values as in real conditions (Błażejczyk et al. 2010). UTCI is calculated from the air temperature $\left(\mathrm{Ta},{ }^{\circ} \mathrm{C}\right)$, wind speed at a height of $10 \mathrm{~m}$ $(\mathrm{v}, \mathrm{m} / \mathrm{s})$, vapour pressure $(\mathrm{e}, \mathrm{hPa})$, and the mean radiant temperature $\left(\mathrm{Tmrt},{ }^{\circ} \mathrm{C}\right)$. These factors together determine the current thermal stress which the environment exerts on human beings in the reference conditions. These conditions are set for a man walking at a speed of $4 \mathrm{~km} / \mathrm{h}$ (which is equivalent to metabolic changes of $2.3 \mathrm{MET}$ ), Tmrt is equal to $\mathrm{Ta}$, and the relative humidity for $\mathrm{Ta}<29^{\circ} \mathrm{C}$ is at $50 \%$, while the value of vapour pressure above $29^{\circ} \mathrm{C}$ is $20 \mathrm{hPa}$. Defining the full terms of UTCI is very time-consuming; therefore, for testing, as recommended by Fiala et al. (2012) a regression model based on the 6th degree polynomial function was used.

$U T C I=f(T a, v, e, T m r t)$

The scale of thermal stress was taken from the physiological model and is presented in the table (Havenith et al. 2012).

\subsection{North Atlantic Oscillation}

The North Atlantic Oscillation (NAO) is a macrocirculatory phenomenon occurring in the North Atlantic. It was noticed for the first time by Walker (1924). The pressure difference between the Azorean high and the Icelandic low causes significant changes in meteorological factors such as air temperature, wind speed and precipitation. This affects climate variability from the eastern coast of the USA through Siberia and the Arctic to the subtropical Atlantic (Tomé et al. 2004; Araźny 2019). NAO is one of the circulation systems with the longest history of measurement in the world. Unfortunately, NAO, with its current state of knowledge, is practically an unpredictable phenomenon. Even the best possible linear predictions do not explain more than ca. $10 \%$ of the total NAO variance (Stephenson et al. 2000). The strong impact of NAO on the weather and climate of the northern hemisphere justifies the increasing interest in defining the limits of its predictability, both in the long term and seasonally. Numerous studies have confirmed earlier observations that the greatest influence of NAO on the climate of Europe is visible in the winter period of DJFM (December, January, February, March) (Marsz et al. 2016; Rodwell et al. 1999). For the southwest region of Poland (Lower Silesia), a strong correlation occurs between the NAO Hurrell index (monthly NAO values) and air 
Table 1 Assessment scale of UTCI (Havenith et al. 2012)

\begin{tabular}{ll}
\hline $\mathrm{UTCI}^{\circ} \mathrm{C}$ & Thermal stress categories \\
\hline $\mathrm{UTCI}>46$ & Extreme heat stress \\
$46>\mathrm{UTCI}>38$ & Very strong heat stress \\
$38>\mathrm{UTCI}>32$ & Strong heat stress \\
$32>\mathrm{UTCI}>26$ & Moderate heat stress \\
$26>\mathrm{UTCI}>9$ & No thermal stress \\
$9>\mathrm{UTCI}>0$ & Slight cold stress \\
$0>\mathrm{UTCI}>-13$ & Moderate cold stress \\
$-13>\mathrm{UTCI}>-26$ & Strong cold stress \\
$-26>\mathrm{UTCI}>-40$ & Very strong cold stress \\
$-40>\mathrm{UTCI}$ & Extreme cold stress \\
\hline
\end{tabular}

temperature, saturation deficit as well as evaporation (Marsz and Styszyńska 2015; Marsz et al. 2019).

For the above reasons, this paper focuses on Hurrell's index to investigate the relationship between NAO and UTCI, for both the whole year and winter time. The same goes for its components representing the bioclimatic conditions of Kłodzko.

\subsection{Methodology}

Both Tmrt and UTCI were calculated using the Bioklima 2.6 software (www.igipz.pan.pl) (Błażejczyk 1996). The mean radiant temperature (Tmrt) was calculated according to the SolAlt model form MENEX 2005 (Błażejczyk and Matzarakis 2007) based on the cloudiness and sun altitude above Kłodzko (taken from station's geographical coordinates). UTCI was calculated for each day in 12 UTC (taken as time with the highest human activity). The mean
UTCI values were calculated for each day of the year for 52 years. In seasonal changes, the UTCI was aggregated according to Table 1 and presented as a frequency for each month. To find the relation with NAO, time series was spread on years where Hurrel index was negative (18 years) and positive (34 years). The mean, minimum and maximum UTCI values were compared in these two groups with their counterparts for the tested 52 years. Additionally, a 30-day moving average was calculated to find the quasi-wave nature. Similarly all meteorological components (air temperature, water vapour pressure, wind speed and cloudiness) were analysed. In this article, the dataset contains 18,993 measurements, about $9 \%$ of which are cases were the wind speed is less than $0.5 \mathrm{~m} / \mathrm{s}$ while about $1 \%$ are cases were the air temperature exceeds $29^{\circ} \mathrm{C}$. These cases were not excluded from the study but replaced by limiting the condition of applicably of UTCI, i.e. $\mathrm{v}<0.5$ $\mathrm{m} / \mathrm{s}$ was taken as $0.5 \mathrm{~m} / \mathrm{s}$ and e was taken as $20 \mathrm{hPa}$ at Ta $>29^{\circ} \mathrm{C}$.

\section{Results}

\subsection{Annual and seasonal variability of the UTCI}

In the period 1966-2017, the range of bioclimatic conditions varies over the years. In winter, the range of UTCI change between about -50 and $10^{\circ} \mathrm{C}$, while in summer it is reduced to between about 0 and $30^{\circ} \mathrm{C}$ of UTCI (Fig. 2). This is also reflected by the biggest standard deviation (sd) values of monthly UTCI variability in winter (Dec-Mar). The UTCI annual average value in Kłodzko fluctuated between $0.56{ }^{\circ} \mathrm{C}$ in 1985 and $5.73{ }^{\circ} \mathrm{C}$ in 2003 (Table 2). Changes
Fig. 2 Annual course of UTCI in Kłodzko 1966-2017

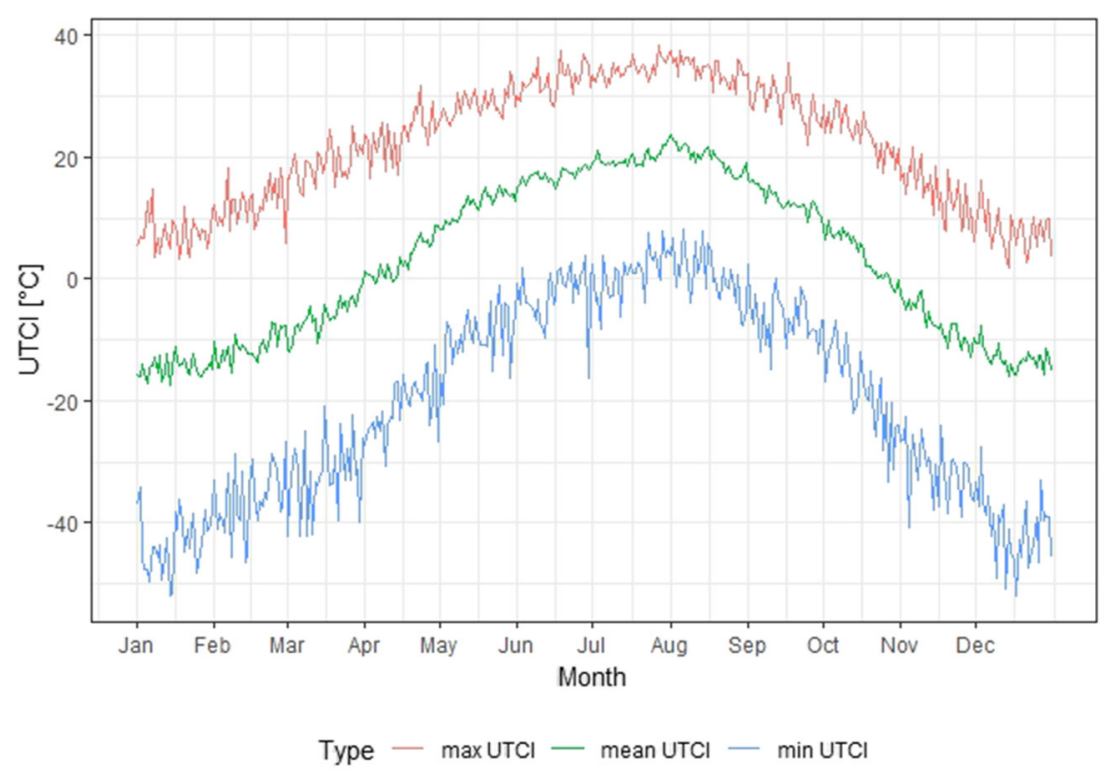

Data from IMGW-PiB 
Table 2 Mean monthly and annual values of UTCI index in particular years in 1966-2017 in Kłodzko

\begin{tabular}{|c|c|c|c|c|c|c|c|c|c|c|c|c|c|}
\hline Year & Jan & Feb & Mar & Apr & May & Jun & Jul & Aug & Sep & Oct & Nov & Dec & Jan-De \\
\hline 1966 & -12.08 & -3.19 & -5.47 & 8.70 & 14.18 & 20.03 & 18.15 & 17.54 & 13.72 & 9.78 & -5.19 & -10.40 & 5.48 \\
\hline 1967 & -14.66 & -16.26 & -9.71 & -0.98 & 11.78 & 16.44 & 23.16 & 19.19 & 15.49 & 6.90 & -5.26 & -18.77 & 2.28 \\
\hline 1968 & -23.58 & -13.40 & -9.51 & 7.04 & 7.79 & 16.09 & 16.45 & 17.51 & 12.81 & 5.31 & -5.17 & -14.34 & 1.42 \\
\hline 1969 & -19.90 & -15.28 & -10.49 & 1.10 & 14.39 & 13.89 & 21.75 & 15.77 & 15.50 & 8.34 & -9.84 & -15.54 & 1.64 \\
\hline 1970 & -20.37 & -20.01 & -8.76 & -3.45 & 10.00 & 18.38 & 16.94 & 19.76 & 13.22 & 1.87 & -5.46 & -8.93 & 1.10 \\
\hline 1971 & -10.55 & -11.17 & -6.20 & 6.06 & 15.40 & 14.34 & 20.86 & 21.10 & 10.18 & 5.81 & -8.33 & -6.69 & 4.23 \\
\hline 1972 & -14.96 & -10.33 & -2.43 & 0.06 & 9.34 & 15.21 & 20.82 & 17.41 & 10.76 & 1.58 & -5.87 & -8.20 & 2.78 \\
\hline 1973 & -8.41 & -9.48 & 1.01 & -1.75 & 13.85 & 17.66 & 19.08 & 24.27 & 15.69 & 2.13 & -11.73 & -16.98 & 3.78 \\
\hline 1974 & -13.95 & -5.18 & 2.22 & 4.40 & 9.73 & 12.58 & 13.19 & 20.88 & 13.48 & -5.52 & -9.05 & -9.65 & 2.76 \\
\hline 1975 & -9.89 & -5.48 & -4.24 & 1.53 & 13.00 & 14.55 & 20.44 & 21.57 & 18.12 & 5.44 & -8.84 & -13.99 & 4.35 \\
\hline 1976 & -18.40 & -10.93 & -8.80 & 2.89 & 12.47 & 17.93 & 21.39 & 16.00 & 9.21 & 4.01 & -6.36 & -15.58 & 1.99 \\
\hline 1977 & -14.25 & -8.25 & -3.68 & -2.15 & 9.46 & 19.28 & 17.41 & 17.19 & 8.37 & 10.79 & -11.84 & -13.22 & 2.43 \\
\hline 1978 & -20.39 & -12.93 & -4.33 & 1.35 & 7.38 & 15.72 & 16.11 & 14.08 & 5.54 & 5.46 & -4.52 & -14.16 & 0.78 \\
\hline 1979 & -19.53 & -11.85 & -10.13 & -0.54 & 14.39 & 20.53 & 14.61 & 19.02 & 16.01 & 4.71 & -5.34 & -7.54 & 2.86 \\
\hline 1980 & -13.78 & -3.47 & -8.07 & 2.33 & 9.38 & 15.00 & 15.24 & 19.34 & 16.17 & 2.86 & -7.51 & -10.43 & 3.09 \\
\hline 1981 & -11.06 & -10.67 & -1.16 & 7.78 & 13.94 & 18.66 & 17.76 & 19.98 & 14.79 & 1.46 & -10.92 & -13.68 & 3.91 \\
\hline 1982 & -13.28 & -11.79 & -4.58 & -2.45 & 14.19 & 18.35 & 21.96 & 20.03 & 20.85 & 4.41 & -5.73 & -10.21 & 4.31 \\
\hline 1983 & -14.54 & -15.14 & -6.50 & 2.92 & 13.09 & 16.70 & 24.32 & 21.01 & 12.75 & 4.33 & -8.85 & -17.98 & 2.68 \\
\hline 1984 & -14.37 & -13.91 & -8.07 & 0.77 & 8.71 & 11.98 & 13.85 & 21.00 & 7.35 & 4.13 & -9.29 & -10.65 & 0.96 \\
\hline 1985 & -19.81 & -20.79 & -10.64 & -1.73 & 12.16 & 9.41 & 21.11 & 18.00 & 11.28 & 7.42 & -11.46 & -8.24 & 0.56 \\
\hline 1986 & -17.99 & -16.36 & -8.90 & 1.46 & 15.90 & 17.02 & 19.79 & 18.43 & 9.24 & 5.42 & -2.51 & -15.58 & 2.16 \\
\hline 1987 & -20.34 & -10.79 & -12.99 & 3.24 & 8.67 & 15.79 & 19.69 & 14.49 & 14.87 & 2.11 & -8.24 & -12.72 & 1.15 \\
\hline 1988 & -12.63 & -13.20 & -12.21 & 4.02 & 12.43 & 16.36 & 20.46 & 20.62 & 11.50 & 2.41 & -10.39 & -15.24 & 2.01 \\
\hline 1989 & -8.96 & -11.50 & -1.52 & 2.07 & 12.30 & 16.51 & 20.52 & 19.15 & 16.48 & 6.09 & -6.20 & -10.10 & 4.57 \\
\hline 1990 & -12.21 & -6.13 & -1.50 & 3.96 & 16.63 & 16.06 & 18.44 & 23.05 & 7.64 & 5.00 & -7.44 & -16.02 & 3.96 \\
\hline 1991 & -10.23 & -11.92 & -0.50 & 2.53 & 5.79 & 13.75 & 22.73 & 19.77 & 16.31 & 5.50 & -8.85 & -12.72 & 3.51 \\
\hline 1992 & -11.74 & -8.28 & -5.63 & 0.93 & 12.59 & 21.01 & 23.57 & 27.80 & 16.01 & 0.78 & -10.23 & -10.54 & 4.69 \\
\hline 1993 & -15.57 & -6.32 & -5.45 & 7.12 & 17.52 & 16.05 & 16.92 & 20.85 & 13.26 & 5.11 & -11.04 & -12.43 & 3.84 \\
\hline 1994 & -12.09 & -7.18 & -6.14 & 2.22 & 13.53 & 19.26 & 27.22 & 23.05 & 15.74 & 4.81 & -3.42 & -11.18 & 5.49 \\
\hline 1995 & -21.51 & -10.62 & -8.71 & 1.37 & 11.38 & 16.79 & 25.90 & 21.52 & 9.91 & 10.53 & -8.49 & -15.31 & 2.73 \\
\hline 1996 & -14.49 & -17.76 & -12.06 & 7.72 & 10.34 & 17.62 & 16.06 & 19.59 & 7.38 & 5.86 & -4.91 & -13.00 & 1.86 \\
\hline 1997 & -11.31 & -8.97 & -0.17 & -3.80 & 11.17 & 19.47 & 20.62 & 24.41 & 18.67 & 0.67 & -4.24 & -10.43 & 4.67 \\
\hline 1998 & -12.44 & -4.18 & -6.66 & 5.72 & 14.81 & 21.01 & 19.40 & 21.24 & 13.49 & 0.56 & -6.11 & -14.25 & 4.38 \\
\hline 1999 & -9.95 & -13.66 & -2.96 & 6.18 & 14.84 & 19.43 & 23.29 & 20.67 & 19.21 & 3.37 & -8.16 & -16.68 & 4.63 \\
\hline 2000 & -15.18 & -9.29 & -6.86 & 10.40 & 17.34 & 19.70 & 15.44 & 24.59 & 14.10 & 6.30 & -2.92 & -6.95 & 5.56 \\
\hline 2001 & -13.06 & -5.81 & -7.47 & 1.76 & 15.81 & 17.28 & 21.46 & 21.75 & 8.81 & 9.51 & -5.59 & -15.04 & 4.12 \\
\hline 2002 & -11.84 & -10.63 & -4.23 & 4.28 & 18.30 & 20.85 & 21.96 & 24.95 & 15.14 & -1.05 & -4.65 & -11.71 & 5.11 \\
\hline 2003 & -12.77 & -5.29 & 1.57 & 1.61 & 16.46 & 23.25 & 20.55 & 24.38 & 15.62 & -2.03 & -1.30 & -13.26 & 5.73 \\
\hline 2004 & -17.54 & -15.10 & -8.33 & 3.50 & 7.93 & 15.00 & 17.73 & 19.39 & 11.72 & 5.66 & -8.29 & -12.28 & 1.62 \\
\hline 2005 & -15.00 & -16.68 & -9.75 & 7.08 & 12.40 & 15.14 & 19.51 & 16.18 & 15.07 & 5.68 & -8.97 & -16.17 & 2.04 \\
\hline 2006 & -13.31 & -12.29 & -13.26 & 5.68 & 9.01 & 18.80 & 26.30 & 13.20 & 17.54 & 6.02 & -5.08 & -8.58 & 3.67 \\
\hline 2007 & -15.73 & -9.56 & -4.29 & 8.67 & 12.61 & 18.44 & 17.76 & 20.73 & 8.76 & 2.42 & -13.43 & -13.14 & 2.77 \\
\hline 2008 & -16.66 & -9.04 & -10.14 & 3.43 & 13.59 & 18.03 & 18.51 & 17.95 & 9.44 & 5.57 & -8.62 & -15.01 & 2.25 \\
\hline 2009 & -11.99 & -15.63 & -9.17 & 10.82 & 10.35 & 11.74 & 18.32 & 21.98 & 15.82 & -0.24 & -6.86 & -13.19 & 2.66 \\
\hline 2010 & -14.49 & -15.35 & -9.31 & 4.54 & 6.93 & 17.81 & 23.21 & 17.29 & 9.33 & -1.31 & -6.16 & -22.91 & 0.80 \\
\hline 2011 & -10.78 & -14.41 & -3.12 & 6.65 & 13.94 & 17.91 & 14.92 & 19.43 & 16.24 & 4.10 & -3.16 & -17.63 & 3.67 \\
\hline 2012 & -16.96 & -18.20 & -0.14 & 2.37 & 13.27 & 16.02 & 19.40 & 20.26 & 12.25 & 2.82 & -6.07 & -15.77 & 2.44 \\
\hline 2013 & -14.43 & -12.88 & -15.75 & 2.56 & 8.96 & 15.76 & 22.24 & 20.68 & 8.31 & 4.32 & -7.36 & -14.93 & 1.46 \\
\hline 2014 & -14.16 & -12.21 & 2.74 & 7.21 & 7.65 & 16.86 & 22.07 & 16.14 & 14.75 & 4.94 & -2.97 & -12.52 & 4.21 \\
\hline
\end{tabular}


Table 2 (continued)

\begin{tabular}{llllllllllllll}
\hline Year & Jan & Feb & Mar & Apr & May & Jun & Jul & Aug & Sep & Oct & Nov & Dec & Jan-Dec \\
\hline 2015 & -16.69 & -9.68 & -4.96 & 1.66 & 10.16 & 16.98 & 22.17 & 24.30 & 11.33 & 4.39 & -4.42 & -7.48 & 3.98 \\
2016 & -12.01 & -10.69 & -6.04 & 3.70 & 12.99 & 18.45 & 19.86 & 18.15 & 19.47 & 0.20 & -10.04 & -11.11 & 3.58 \\
2017 & -17.25 & -6.70 & -2.18 & -0.35 & 13.08 & 18.39 & 18.54 & 21.36 & 8.19 & 2.34 & -9.29 & -15.54 & 2.55 \\
\hline
\end{tabular}

from year to year in terms of monthly and annual UTCI values in a 52-year study in Kłodzko except for April do not show a statistically significant directional trend (Table 2). The upward trend for April is marked by a statistically significant (for $\alpha=0.05$ ) Pearson correlation coefficient that is equal to 0.298 and a determination coefficient $R^{2}=$ 0.089. Non-parametric tests, Kendall ( $r=0.223)$ and Spearman $(r=0.318)$, confirm the importance of the upward trend in the April UTCI values for Kłodzko (Table 2), which documents significant fluctuations in monthly values from year to year.

In the case of April, the range of these fluctuations is determined by the UTCI amplitude of $14.62{ }^{\circ} \mathrm{C}$, which is formed by the UTCI values $-3.80{ }^{\circ} \mathrm{C}$ in 1997 and $10.82^{\circ} \mathrm{C}$ in 2009. Compared with other months, the amplitude is close to the median and average annual amplitude of monthly UTCI values. The extreme high amplitudes of UTCI are characteristic of March $\left(18.49^{\circ} \mathrm{C}\right.$, its values are $-15.75^{\circ} \mathrm{C}$ for 2013 and $2.74{ }^{\circ} \mathrm{C}$ for 2014) and February $\left(17.60{ }^{\circ} \mathrm{C}\right.$, made up of $-20.89^{\circ} \mathrm{C}$ in 1985 and $3.19^{\circ} \mathrm{C}$ for 1966). The lowest amplitudes, in turn, are the distinguishing feature of November $\left(12.13{ }^{\circ} \mathrm{C}\right.$, its values are $-13.43{ }^{\circ} \mathrm{C}$ for 2007 and $-1.30{ }^{\circ} \mathrm{C}$ in 2003) and May $\left(12.51^{\circ} \mathrm{C}\right.$, formed by the values of $18.30{ }^{\circ} \mathrm{C}$ for 2002 and $5.79{ }^{\circ} \mathrm{C}$ in 1991). The connection with the NAO phases will become clear after further analysis (Section 3.2). In the course of the year, the lowest daily UTCI values for Kłodzko occur in

Table 3 Basic statistic of monthly UTCI variability in Kłodzko in 1966-2017

\begin{tabular}{lllllll}
\hline Mon & Mean & SD & Min & Pctl (25) & Pctl (75) & Max \\
\hline Jan & -14.59 & 3.49 & -23.58 & -16.76 & -12.06 & -8.41 \\
Feb & -11.26 & 4.20 & -20.79 & -14.03 & -8.79 & -3.19 \\
Mar & -6.07 & 4.28 & -15.75 & -9.20 & -3.08 & 2.74 \\
Apr & 3.15 & 3.47 & -3.80 & 1.28 & 5.80 & 10.82 \\
May & 12.17 & 2.99 & 5.79 & 9.66 & 14.18 & 18.30 \\
Jun & 17.02 & 2.60 & 9.41 & 15.75 & 18.50 & 23.25 \\
Jul & 19.79 & 3.15 & 13.19 & 17.75 & 21.96 & 27.22 \\
Aug & 19.96 & 2.98 & 13.20 & 17.98 & 21.40 & 27.80 \\
Sep & 13.13 & 3.65 & 5.54 & 9.79 & 15.76 & 20.85 \\
Oct & 4.02 & 3.18 & -5.52 & 2.12 & 5.66 & 10.79 \\
Nov & -7.15 & 2.75 & -13.43 & -8.99 & -5.18 & -1.30 \\
Dec & -12.97 & 3.36 & -22.91 & -15.36 & -10.43 & -6.69 \\
\hline
\end{tabular}

the December-February period (Fig. 2). The lowest average monthly value of UTCI was recorded for January 1968 which was $-23.58{ }^{\circ} \mathrm{C}$ (Table 2), and corresponds to the "Strong cold stress" class (Table 1) In the examined 52-year period, 76 days were recorded with a UTCI value below $-40{ }^{\circ} \mathrm{C}$, which corresponds to "Extreme cold stress". Only 25 such values occurred after 1990. In the years 19662017 , only once did the value of UTCI below $-40{ }^{\circ} \mathrm{C}$ appear on four subsequent days (from 11 to 14 January 1969). The highest (in the sense of the module number) minimum UTCI value occurred in December 2010 which amounted to $-51.9{ }^{\circ} \mathrm{C}$ (Fig. 2). The minimum values in the winter corresponded to the classes of thermal stress from "Strong cold stress" to "Extreme cold stress", which means that when outside, the hands, legs and face should be protected, and physical effort should be increased to avoid frostbite. The standard deviation for the monthly values of UTCI in Kłodzko fluctuated from 2.60 in June to 4.28 in March (Table 3). In the summer, the highest 52-year average monthly value of UTCI in Kłodzko occurred in July at $19.79{ }^{\circ} \mathrm{C}$ (Table 3). The highest monthly UTCI value was recorded there in August 1992 which was $27.8^{\circ} \mathrm{C}$ (Table 2). Over 52 years, 173 values in the UTCI class of $>32^{\circ} \mathrm{C}$ have been recorded, including none in the UTCI class $>46{ }^{\circ} \mathrm{C}$ corresponding to "Extreme heat stress", and one UTCI value $>38^{\circ} \mathrm{C}$ corresponding to "Very strong heat stress". Those last classes are very rare, and it can be assumed that in summer we do not find heat stress disturbing thermal comfort (Bröde et al. 2012). The maximum recorded UTCI value was $38.3^{\circ} \mathrm{C}$, which corresponds to the class of thermal stress "Very strong heat stress". It should then be able to top up fluids to prevent body dehydration. The analysis of the occurrence frequency of particular classes of thermal stress shows that, in the years 1966-2017, the classes related to heat stress occurred in June (1.5\%), July (4.5\%) and August $(3.9 \%)$. The most common heat class in summer was "No thermal stress", the frequency of which ranged from $60 \%$ in May to $70 \%$ in June, and then $65-66 \%$ in July and August. The cold classes are from October to April. The "Extreme cold stress" class occurs only in January $(3 \%)$ and in December $(1.5 \%)$, while "Very strong cold stress" fluctuates from $3 \%$ in March to $12 \%$ in January. From November to March, the most frequent classes are "Strong cold stress" (38\% in January, 36\% in December and February) and "Moderate cold stress" (25\% in November 
and March). On a yearly time scale, the most common class of thermal stress is "No thermal stress" (34\%), followed by "Moderate cold stress" (23\%) and "Slight cold stress" (18\%), with the lower frequency of classes related to heat stress: "Strong head stress" and "Moderate heat stress" (14\% and 5\%, respectively).

In Poland, the greatest impact of the North Atlantic Oscillation on climate can be observed in the earlywinter and winter (Degirmendzić et al. 2002; Wibig 2000; Niedźwiedź 2002). Therefore, similar relationships can also be expected for macro-climatic conditions of the Kłodzko bioclimate, but this requires verification of the undermentioned analysis. With this in mind, the analysed years were divided into two groups representing either the negative or positive winter index of the Hurrell NAO. In the years 1966-2017, there were 34 years in which the Hurrell winter indicator was positive and 18 years in which it was negative. The mean, minimum and maximum UTCI values were compared in these two groups with their counterparts for the entire tested 52 years, e.g. UTCI for the phase group - UTCI for all 52 years (Fig. 4). The calculated difference in average daily UTCI values for the negative NAO group in the annual course is characterised by a larger variability (amplitude of these UTCI differences is from -6 to $6{ }^{\circ} \mathrm{C}$ upper graph Fig. 4). In comparison to the 52-year period, the monthly moving average of UTCI (upper graph Fig. 4 - green line) is lower in the period from January to October for the negative phase.
When the Hurrell index is positive, the variability in mean daily UTCI values is lower and oscillates between -2 and $3{ }^{\circ} \mathrm{C}$. The middle graphs (Fig. 4) show how maximum values of UTCI in the negative and positive Hurrell index vary in comparison with the 52-year period. The negative group of the Hurrell (left graph) index is characterised with lower values of the maximum heat stress which is shown by bigger differences in comparison with the positive group (right graph). These indicate a relatively strong relationship between the positive phase with the occurrence of high daily values of UTCI. On the other hand, differences between the minimum values of UTCI (Fig. 4) show a significant difference only in the period NovemberDecember. Figure 4 also presents their quasi-wave nature, which was exposed by the 30-day moving average of the analysed UTCI differences (upper graph). The maximum daily values of UTCI for Kłodzko in the positive phase of the NAO are much more common than in the case of the negative phase, and are also equal to the maximum values for the entire 52-year period. The minimum values of the analysed differences are marked by a comparable discrepancy for both periods. As a consequence, with a significant prevalence of the UTCI average attendance over the incidence of extreme UTCI values (Fig. 3), we can observe a weak, statistically unreliable upward trend in the annual UTCI values. A different approach in terms of meteorological parameters differences, as shown in Fig. 5, enables us to present additional information on the impact
Fig. 3 Frequency of thermal classes for months in Kłodzko, 1966-2017

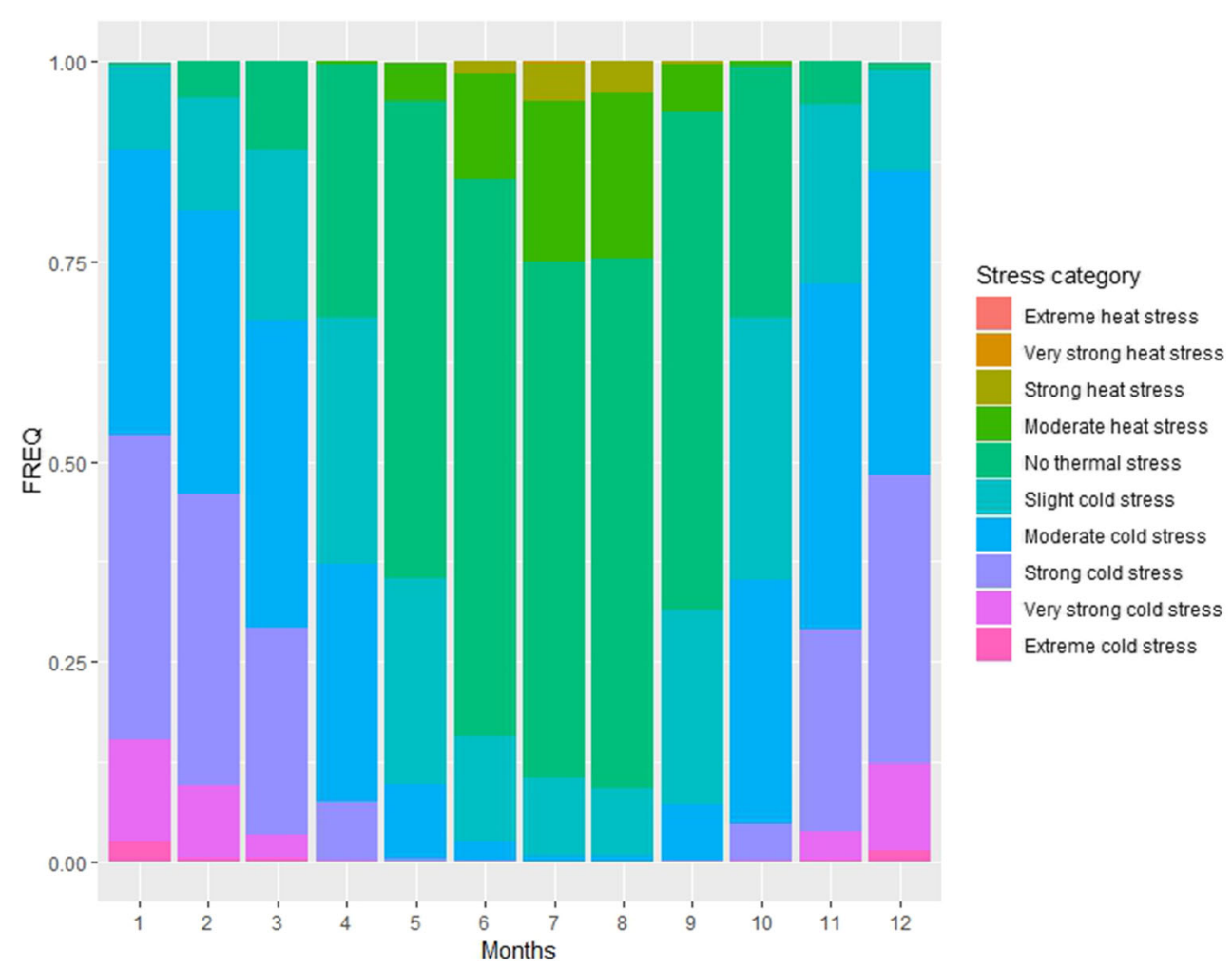


of NAO phasic changes on UTCI. This is provided by the annual waveforms of the differences between the NAO phases (positive phase-negative phase) for the average daily values of the UTCI index and its analysed components (air temperature, vapour pressure, wind speed, cloudiness), all of which are shown in successive graphs in Fig. 5. They document that the highest differences in the UTCI index for Kłodzko occur in the late winter-early spring period (from the last days of February to the first days of April). They also indicate an increase in the mean daily values of UTCI in this period for the years with a NAO positive phase, reaching approx. $8-9^{\circ} \mathrm{C}$. This increase is not compensated by days with negative differences occurring during the year, which, apart from the late autumn (from mid-November to mid-December) happen less frequently than positive differences, and tend to have lower values. In the aforementioned late Autumn, sporadically negative values can reach about $7-8^{\circ} \mathrm{C}$.

A comparison of these differential waveforms (Fig. 4) with the relevant waveforms of the analysed meteorological elements indicates (Fig. 5) that the breakthroughs in winter and spring, i.e. the period of inter-phase increase in UTCI values, are related mainly to positive differences typical for air temperature and vapour pressure. However, the negative differences in the late autumn period are affected by the smaller overcast and higher wind speeds in the positive phase NAO. Each of the meteorological elements that make up the components of UTCI has only the character of the annual course of inter-phase differences (e.g. maximum differences for air temperature in January and for vapour pressure in March). Nevertheless, similar to UTCI waveforms, the elements are characterised by a quasi-wave course of changes and seasonal variation in the amplitude of fluctuations in these differential values.

\subsection{Shaping bioclimatic conditions by North Atlantic Oscillations}

In Poland, the greatest impact of the North Atlantic Oscillation on climate can be observed in the earlywinter and winter (Degirmendzić et al. 2002; Wibig 2000; Niedźwiedź 2002). Therefore, similar relationships can also be expected for macro-climatic conditions of the Kłodzko bioclimate, but this requires verification of the undermentioned analysis. With this in mind, the analysed years were divided into two groups representing either the negative or positive winter index of the Hurrell NAO. In the years 1966-2017, there were 34 years in which the Hurrell winter indicator was positive and 18 years in which it was negative. The mean, minimum and maximum UTCI values were compared in these two groups with their counterparts for the entire tested 52-years, e.g. UTCI for the phase group-UTCI for all 52 years (Fig. 4). The calculated difference in average daily UTCI values for the negative NAO group in the annual course is characterised by a larger variability (amplitude of these UTCI differences is from $-6{ }^{\circ} \mathrm{C}$ to $6{ }^{\circ} \mathrm{C}$ upper graph-Fig. 4). In comparison to the 52-year period, the monthly moving average of UTCI (Fig. 4 upper graph-green line) is lower in the period from January to October for the negative phase. When the Hurrell
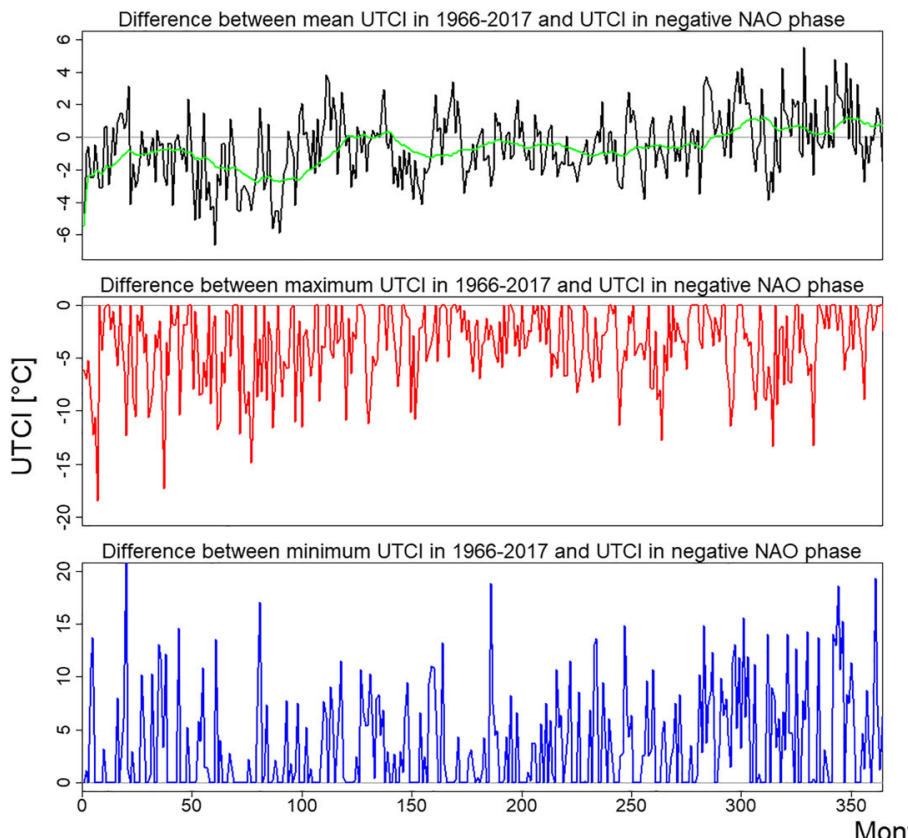

Difference between mean UTCl in 1966-2017 and UTCl in possitive NAO phase

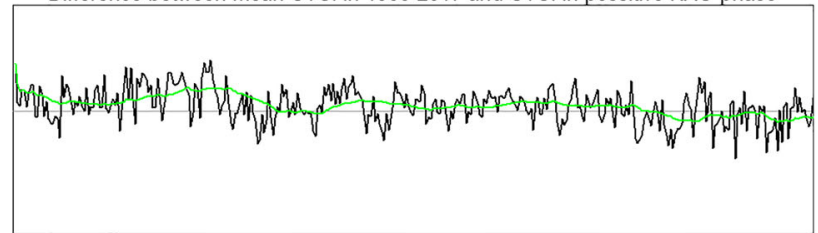

Difference between maximum UTCI in 1966-2017 and UTCI in possitive NAO phase

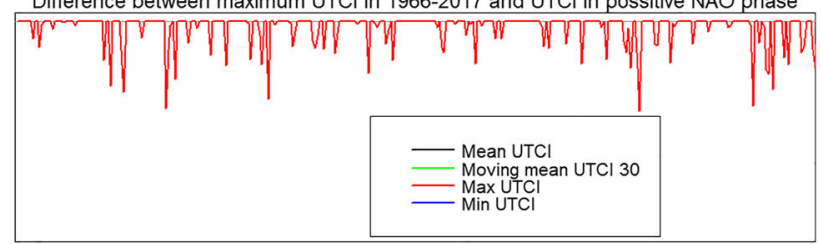

Difference between minimum UTCI in 1966-2017 and UTCI in possitive NAO phase

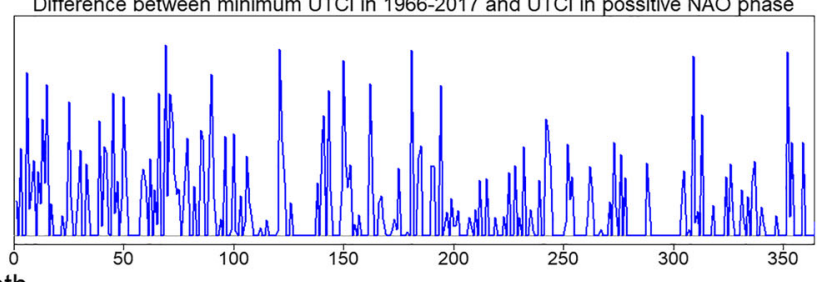

Fig. 4 Annual course of UTCI differences at different NAO index phases, Kłodzko, 1966-2017 

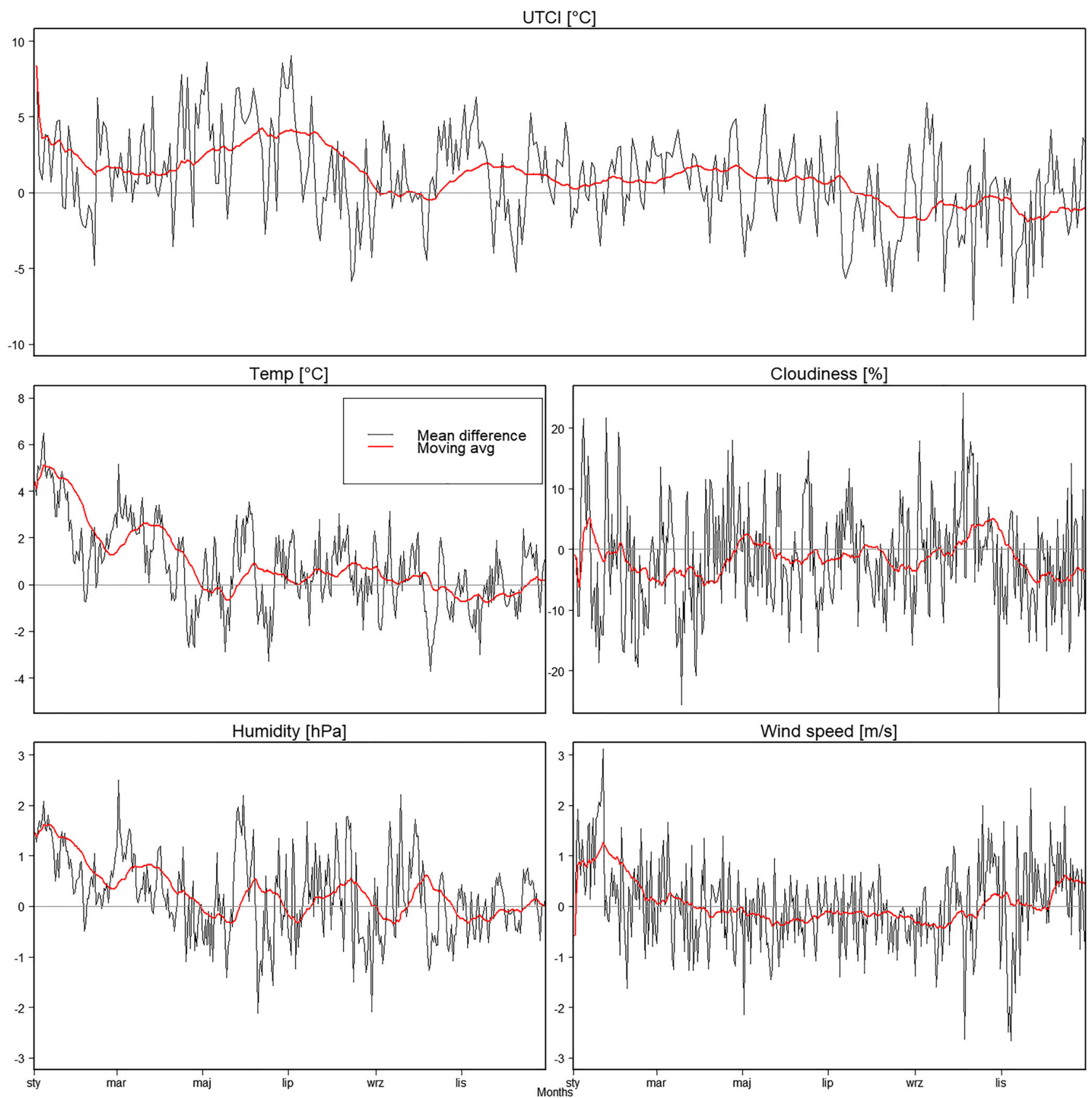

Fig. 5 Annual course of differences in basic meteorological variables at different NAO index phases Kłodzko, 1966-2017

index is positive the variability in mean daily UTCI values is lower and oscillates between $-2{ }^{\circ} \mathrm{C}$ and $3{ }^{\circ} \mathrm{C}$. The middle graphs (Fig. 4) show how maximum values of UTCI in the negative and positive Hurrell index varies in comparison to the 52-year period. The negative group of the Hurrell (left graph) index is characterised with lower values of the maximum heat stress which is shown by bigger differences in comparison to the positive group (right graph). These indicate a relatively strong relationship between the positive phase with the occurrence of high daily values of UTCI.
On the other hand differences between the minimum values of UTCI (Fig. 4) show a significant difference only in the period November-December. Figure 4 also presents their quasi-wave nature, which was exposed by the 30day moving average of the analysed UTCI differences (upper graph). The maximum daily values of UTCI for Kłodzko in the positive phase of the NAO are much more common than in the case of the negative phase, and are also equal to the maximum values for the entire 52-year period. The minimum values of the analysed differences 
Table 4 Correlation coefficient in particular winter (DJFM) and particular months

\begin{tabular}{lllllllllllllll}
\hline & DJFM & Jan & Feb & Mar & Apr & May & Jun & Jul & Aug & Sep & Oct & Nov & Dec \\
\hline Temperature & 0.683 & 0.590 & 0.352 & 0.513 & 0.084 & 0.169 & -0.023 & 0.175 & 0.351 & 0.142 & -0.053 & -0.136 & 0.300 \\
Wind speed & 0.349 & 0.349 & 0.157 & 0.043 & 0.090 & -0.163 & -0.117 & -0.065 & -0.229 & -0.026 & 0.014 & -0.053 & 0.274 \\
Cloudiness & -0.222 & -0.044 & -0.134 & -0.161 & 0.106 & -0.174 & -0.014 & -0.074 & -0.351 & 0.054 & 0.166 & -0.159 & -0.194 \\
Water pressure & 0.661 & 0.567 & 0.356 & 0.478 & 0.142 & 0.102 & -0.039 & 0.118 & 0.039 & 0.238 & 0.013 & -0.071 & 0.285 \\
UTCI & 0.414 & 0.222 & 0.274 & 0.467 & 0.033 & 0.221 & 0.050 & 0.167 & 0.419 & 0.101 & -0.080 & -0.119 & 0.079 \\
\hline
\end{tabular}

are marked by a comparable discrepancy for both periods. As a consequence, with a significant prevalence of the UTCI average attendance over the incidence of extreme UTCI values (Fig. 3), we can observe a weak, statistically unreliable upward trend in the annual UTCI values. A different approach in terms of meteorological parameters differences, as shown in Fig. 5, enables us to present additional information on the impact of NAO phasic changes on UTCI. This is provided by the annual waveforms of the differences between the NAO phases (positive phase-negative phase) for the average daily values of the UTCI index and its analysed components (air temperature, vapor pressure, wind speed, cloudiness), all of which are shown in successive graphs in Fig. 5. They document that the highest differences in the UTCI index for Kłodzko occur in the late winter-early spring period (from the last days of February to the first days of April). They also indicate an increase in the mean daily values of UTCI in this period for the years with a NAO positive phase, reaching approx. $8-9{ }^{\circ} \mathrm{C}$. This increase is not compensated by days with negative differences occurring during the year, which, apart from the late autumn (from mid-November to midDecember) happen less frequently than positive differences, and tend to have lower values. In the aforementioned late Autumn, sporadically negative values can reach about 7-8 ${ }^{\circ} \mathrm{C}$.

A comparison of these differential waveforms (Fig. 4) with the relevant waveforms of the analysed meteorological elements indicates (Fig. 5) that the breakthroughs in winter and spring, i.e. the period of inter-phase increase in UTCI values, are related mainly to positive differences typical for air temperature and vapor pressure. However, the negative differences in the late autumn period are affected by the smaller overcast and higher wind speeds in the positive phase NAO. Each of the meteorological elements that make up the components of UTCI has only the character of the annual course of inter-phase differences (e.g. maximum differences for air temperature in January and for vapor pressure in March). Nevertheless, similar to UTCI waveforms, the elements are characterised by a quasi-wave course of changes and seasonal variation in the amplitude of fluctuations in these differential values.

\subsection{Correlations between monthly NAO and monthly UTCI values in Kłodzko}

The explanation as to the genesis of differences in the UTCI values, as described in Section 3.2 well as in the components of meteorological elements of this index and thus the capturing of NAO's role in their shaping, requires additional statistical verification using correlation analysis and various tests on the significance of the results obtained. The results of such analysis and testing of the significance of the obtained linear correlation coefficients (as presented by the Pearson parametric test and the nonparametric Kendall and Spearman tests) clearly confirm the strong influence of NAO upon the bioclimatic conditions of Kłodzko in winter. In the winter period, the DJFM noted that the air temperature is significantly correlated with the winter Hurrell NAO indicator. Here, Pearson's linear correlation coefficient (Table 4) was $R=0.683$ and $R^{2}=0.466$. Similarly the high value of the correlation coefficient marks the relationship of winter the NAO with vapour pressure, because $R=0.661, R^{2}=0.437$. The correlation between UTCI and the Hurrell's NAO indicator reached a value of $R=0.414\left(R^{2}=0.171\right)$, which in the 52-years test, according to Pearson, can be considered statistically significant $(R>0.273)$. Weaker $(R=0.349$, $R^{2}=0.122$ ) but a statistically significant correlation can be found between NAO and wind speed. In individual months, the correlation between the Hurrell NAO indicator and air temperature is highest in January $(R=0.590)$ and March ( $R=0.5130)$. Statistically significant results were also obtained in February, August and December (Table 4). The impact of NAO is therefore statistically significant during the winter period of the DJFM and in August. Similar values were obtained for water vapour volatility, which according to Pearson's linear correlation is significantly squeezed from NAO in January, February, March and December. In August, the coefficient of this correlation does not exceed the statistical significance threshold, since $R=0.238$. Wind velocity is statistically and significantly dependent on NAO in January and December, whereas cloudiness is significantly but inversely correlated in August $(R=$ -0.351). The correlation coefficient for UTCI is significant in February, March $(R=0.467)$, and August (Table 4). 


\section{Discussion}

The average annual values of the UTCI correspond to the thermal class "Slight cold stress". These results are lower than the UTCI values for other areas of Poland due to the submontane character of Kłodzko. For comparison, Rozbicka and Rozbicki (2018) obtained for Warsaw around 3.5 to $9.3{ }^{\circ} \mathrm{C}$ in $1998-2015$, and Mąkosza (2013) for Lubuskie Voivodeship gave a range of UTCI fluctuations from $6.1^{\circ} \mathrm{C}$ (for Zielona Góra and Gorzów Wielkopolski) to $8.1{ }^{\circ} \mathrm{C}$ in Słubice. In the years 1991-2000, Błażejczyk and Kunert (2011) showed the lowest for Warsaw value with a UTCI indicator of $4.1{ }^{\circ} \mathrm{C}$. Similar absolute minimum values of UTCI were obtained by Mąkosza (2013) and Błażejczyk et al. (2014). In Gorzów Wielkopolski, the absolute minimum was $-54.8^{\circ} \mathrm{C}$ (Mąkosza 2013), while in Warsaw it was $-51.9^{\circ} \mathrm{C}$ (Błażejczyk et al. 2014). All these absolute minimum values correspond to the classes of thermal stress "Extreme cold stress". Comparable results were recorded in other parts of Poland (Rozbicka and Rozbicki 2018; Kuchcik et al. 2013), with a predominance of cold classes, which is probably due to the submontane character of Kłodzko. In studies by Rozbicka and Rozbicki (2018) for Warsaw in the years 1998-2015, a value of $39.5{ }^{\circ} \mathrm{C}$ was obtained, while Mąkosza (2013) obtained $43.1^{\circ} \mathrm{C}$ for Słubice, $41.9^{\circ} \mathrm{C}$ for Gorzów Wielkopolski and $40.4{ }^{\circ} \mathrm{C}$ for Zielona Góra. These values, although higher than those for Kłodzko, are in the same class of thermal stress. The average attendance of UTCI thermal classes in particular months of the year for Kłodzko in the years 1966-2017 is presented in the subsequent diagrams (Fig. 3). The legend placed on the side of the figure shows the terminological and graphical characteristics of these classes. Similar to other parts of Poland (Błażejczyk et al. 2014; Kuchcik et al. 2013; Mąkosza 2013; Rozbicka and Rozbicki 2018), the most favourable biometeorological conditions occur in Kłodzko from April to October. This phenomenon is observed throughout the entire period 1966-2017, even though its intensity and some variation are associated with long-term weather variability, controlled by macrocirculatory factors including the synchronous and nonsynchronous effect of the winter Hurrell's NAO index. In summer, the majority of thermal stress categories represent classes that do not cause heat stress in Kłodzko and oscillate between 70\% in June and 59\% in May. Weather conditions that triggered heat stress were sporadic and amounted to around $2 \%$. In summer, UTCI values fluctuated between -8 and $38{ }^{\circ} \mathrm{C}$. In winter, classes causing cold stress occurred with a frequency of around $15 \%$, which is a value higher than that in the southern part of Warsaw (Rozbicka and Rozbicki 2018). However, Kłodzko is a submontane small town, which thus affects any increase in the frequency of cold stress classes. In winter, there is no heat stress, and
"Slight cold stress" occurs with a frequency of around $40 \%$. The analysed 52-year period is distinctly longer than 10 years (Błażejczyk et al. 2014; Kuchcik et al. 2013) and 17 years (Rozbicka and Rozbicki 2018) in cited works on UTCI in Poland. It has thus allowed for the a possibility of representative analysis of long-term bioclimatic changes in Kłodzko and its surroundings. The executed comparison of bioclimatic features of Kłodzko in two different NAO periods accentuates the fundamental role of macrocirculation conditions and their changes in the formation of the main components of UTCI. The long-term variability of these components in Poland was an issue for many works, e.g. Marsz and Styszyńska (2015). The current analysis not only confirms the results of these studies but also shows how the UTCI in Kłodzko has been formed in relation to phase changes of the winter Hurrell's NAO index. Such an analysis marks a new research approach in Polish studies on UTCI.

\section{Conclusions}

The paper provides an analysis of the macrocirculation origin of changes in the UTCI for Kłodzko and its meteorological elements for the period 1966-2017. The impact of NAO on the UTCI indicator in Kłodzko is strongest in the period December-March. It manifested itself in the differences in UTCI values over the years when the NAO Hurrell (DJFM) indicator was correlated with positive years, and similarly for the years when it was negative. The significant values of the correlation coefficients between the Hurrell NAO index and the bioclimatic values tested are UTCI $R=0.414$, temperature $R=0.683$, water vapour $R=0.661$, and wind speed $R$ $=0.349$. Below the threshold of statistical significance, it was cloudy $(R=0.222)$. In the years 1966-2017, significant statistical dependencies, albeit weaker than those in the winter period, also occurred for air temperature, cloudiness, and UTCI in August. We do not know the reason why these relatively high asynchronous correlational relationships occurred in the summer. This is an issue that needs to be clarified. An important role in the formation of UTCI and NAO relations is played by air temperature and water vapour density which, to a large extent, determine the value of UTCI. The annual course in the average daily value of the UTCI differences and its components for the years 1966-2017 (with both positive and negative winter Hurrell NAO indices) is quasi-wave in character. However, for all the examined elements, the course of seasonal changes is usually asynchronous.

Funding The research is co-financed under the Leading Research Groups support project from the subsidy increased for the period 2020-2025 in the amount of 2\% of the subsidy referred to Art. 387 (3) 
of the Law of 20 July 2018 on Higher Education and Science, obtained in 2019.

Open Access This article is licensed under a Creative Commons Attribution 4.0 International License, which permits use, sharing, adaptation, distribution and reproduction in any medium or format, as long as you give appropriate credit to the original author(s) and the source, provide a link to the Creative Commons licence, and indicate if changes were made. The images or other third party material in this article are included in the article's Creative Commons licence, unless indicated otherwise in a credit line to the material. If material is not included in the article's Creative Commons licence and your intended use is not permitted by statutory regulation or exceeds the permitted use, you will need to obtain permission directly from the copyright holder. To view a copy of this licence, visit http:// creativecommonshorg/licenses/by/4.0/.

\section{References}

Araźny A (2019) Temporal and spatial variability of thermal and humidity stimuli in the Hornsund area (Svalbard). Pol Polar Res 40(1):29-53. https://doi.org/10.24425/ppr.2019.126346

Araźny A, Wyszyński P, Przybylak R (2019) A comparison of bioclimatic conditions on Franz Josef Land (the Arctic) between the turn of the nineteenth to twentieth century and present day. Theoret Appl Climatol 137(3):2623-2638. https://doi.org/10.1007/s00704018-02763-y

Arnoldy I (1962) Acclimati of the man in north and south. Medgiz, Moscow. (in Russian)

Berlato MA, Farenzena H, Fontana DC (2005) Association between El Nino southern oscillation and corn yield in Rio Grande do Sul State. Pesqui Agropecu Brasileira 40(5):423-432. https://doi.org/ 10.1590/S0100-204X2005000500001

Błażejczyk K (1996) BioKlima 2.6. Institute of Geography and Spatial Organization (http://www.igipz.pan.pl/Bioklima-zgik.html), (Online; accessed 19 Jan 2019)

Błażejczyk K (2011) Assessment of regional bioclimatic contrasts in Poland. Misc Geogr-Region Stud Dev 15:79-91. https://doi.org/ 10.2478/v10288-012-0004-7

Błażejczyk K, Kunert A (2011) Bioclimatic principles of recreation and tourism in Poland (in Polish), vol 13

Błażejczyk K, Matzarakis A (2007) Assessment of bioclimatic differentiation of Poland based on the human heat balance. Geogr Polonica 80(1):63-82

Błażejczyk K, Bröde P, Fiala D, Havenith G, Holmér I, Jendritzky G, Kampmann B, Kunert A (2010) Principles of the new Universal Thermal Climate Index (UTCI) and its application to bioclimatic research in European scale. Misc Geogr 14(2010):91102. https://doi.org/10.2478/mgrsd-2010-0009

Błażejczyk K, Epstein Y, Jendritzky G, Staiger H, Tinz B (2012) Comparison of UTCI to selected thermal indices. Int J Biometeorol 56(3):515-535. https://doi.org/10.1007/s00484-011-0453-2

Błażejczyk K, Kuchcik M, Błażejczyk A, Milewski P, Szmyd J (2014) Assessment of urban thermal stress by UTCI-experimental and modelling studies: an example from Poland. DIE ERDE-J Geogr Soc Berlin 145(1-2):16-33. https://doi.org/10.12854/erde-145-3

Bröde P, Krüger EL, Rossi FA, Fiala D (2012) Predicting urban outdoor thermal comfort by the Universal Thermal Climate Index UTCI- a case study in Southern Brazil. Int J Biometeorol 56(3):471-480. https://doi.org/10.1007/s00484-011-0452-3

Bryś K, Ojrzyńska H (2016) Stimulating qualities of biometeorological conditions in Wrocław (in Polish). Acta Geogr Lodz 104:193200
Chabior M (2011) Selected aspects of the bioclimate of Szczecin (in Polish). Prace Stud Geogr 47:293-300

Coutts AM, White EC, Tapper NJ, Beringer J, Livesley SJ (2016) Temperature and human thermal comfort effects of street trees across three contrasting street canyon environments. Theoret Appl Climatol 124(1-2):55-68. https://doi.org/10.1007/s00704-0161832-8

Czernecki B, Głogowski A, Nowosad J (2020) Climate: an R package to access free in-situ meteorological and hydrological datasets for environmental assessment. Sustainability 12(1). https://doi. org/10.3390/su12010394. https://www.mdpi.com/2071-1050/12/ $1 / 394$

De Freitas C, Grigorieva E (2014) The impact of acclimatization on thermophysiological strain for contrasting regional climates. Int J Biometeorol 58(10):2129-2137. https://doi.org/10.1007/s00484014-0813-9

de Freitas CR, Grigorieva EA (2017) A comparison and appraisal of a comprehensive range of human thermal climate indices. Int $\mathrm{J}$ Biometeorol 61(3):487-512. https://doi.org/10.1007/s00484-016$1228-6$

Degirmendzić J, Kożuchowski K, Żmudzka E (2002) Impact of atmospheric circulation on air temperature in Warsaw during months with extreme values of the NAO index (1951-2015) (in Polish). Prz Geofiz 1-2:93-98

Di Napoli C, Pappenberger F, Cloke HL (2018) Assessing heat-related health risk in Europe via the universal thermal climate index (UTCI). Int J Biometeorol 62(7):1155-1165. https://doi.org/10. 1007/s00484-018-1518-2

Diniz FR, Iwabe CMN, Piacenti-Silva M (2019) Valuation of the human thermal discomfort index for the five Brazilian regions in the period of El Nino-Southern Oscillation (ENSO). Int J Biometeorol 63(11):1507-1516. https://doi.org/10.1007/s00484-018-1622-3

Epstein Y, Moran DS (2006) Thermal comfort and the heat stress indices. Ind Health 44(3):388-398. https://doi.org/10.2486/indhealth.44. 388

Fiala D, Lomas KJ, Stohrer M (1999) A computer model of human thermoregulation for a wide range of environmental conditions: the passive system. J Appl Physiol 87(5):1957-1972. https://doi.org/10.1152/jappl.1999.87.5.1957

Fiala D, Lomas KJ, Stohrer M (2001) Computer prediction of human thermoregulatory and temperature responses to a wide range of environmental conditions. Int J Biometeorol 45(3):143-159. https://doi.org/10.1007/s004840100099

Fiala D, Havenith G, Bröde P, Kampmann B, Jendritzky G (2012) UTCI-Fiala multi-node model of human heat transfer and temperature regulation. Int J Biometeorol 56(3):429-441. https://doi.org/10.1007/s00484-011-0424-7

Ge Q, Kong Q, Xi J, Zheng J (2017) Application of UTCI in China from tourism perspective. Theoret Appl Climatol 128(3-4):551561. https://doi.org/10.1007/s00704-016-1731-z

Gregorczuk M (1968) Bioclimates of the world related to air enthalpy. Int J Biometeorol 12(1):35-39. https://doi.org/10.1007/ BF01552976

Grimm AM, Ferraz SE, Gomes J (1998) Precipitation anomalies in southern Brazil associated with El Niño and La Niña events. J Clim 11(11):2863-2880

Haldane J (1905) The influence of high air temperatures no. i. Epidemiol Infect 5(4):494-513. https://doi.org/10.1017/S0022172 6811

Havenith G, Fiala D, Błazejczyk K, Richards M, Bröde P, Holmér I, Rintamaki H, Benshabat Y, Jendritzky G (2012) The UTCIclothing model. Int J Biometeorol 56(3):461-470

Hurrell J, Staff NCAR (2018) The Climate Data Guide: Hurrell North Atlantic Oscillation (NAO) Index (station-based). (https://cli matedataguide.ucar.edu/climate-data/hurrell-north-atlantic-oscilla tion-nao-index-station-based (Online; Accessed 10-01-2019) 
Idzikowska D (2011) Relationship between mortality and UTCI in Paris, Rome, Warsaw and Budapest(in Polish). Prace Stud Geogr 47:311-318

IMGW (2018) Dane pomiarowo obesrwacyjne (in Polish). https:// dane.imgw.pl/, (Online; accessed 19 Jan 2019)

Jacobs SJ, Pezza AB, Barras V, Bye J (2014) A new 'bio-comfort' perspective for Melbourne based on heat stress, air pollution and pollen. Int J Biometeorol 58(2):263-275. https://doi.org/10.1007/ s00484-013-0636-0

Kane R (1997) Prediction of droughts in north-east Brazil: role of ENSO and use of periodicities. Int $\mathrm{J}$ Climatol: $\mathrm{J} R$ Meteorol Soc 17(6):655-665. https://doi.org/10.1002/(SICI)10970088(199705)17:6<655::AID-JOC144>3.0.CO;2-1

Kozłowska-Szczęsna T, Krawczyk B, Błażejczyk K (2004) The main features of bioclimatic conditions at Polish health resorts. Geogr Polonica 77(1):45-61

Kuchcik M, Błażejczyk K, Szmyd J, Milewski P, Błażejczyk A, Baranowski J (2013) Potencjał leczniczy klimatu Polski (in Polish). Wydawnictwo Akademickie SEDNO Spółka z oo

Mąkosza A (2013) Bioclimatic conditions of the Lubuskie Voivodeship (in Polish). Geogr Polonica 86(1):37-46

Marsz A, Styszyńska A (2015) The variability of atmospheric pressure in the Arctic region of the Atlantic and the temperature in Poland. Contribution to the Manifestations of "European Monsoon" (in Polish). Prz Geofiz 1-2:3-25

Marsz A, Styszyńska A, Krawczyk W (2016) Long-term fluctuations of annual discharges of the main rivers in Poland and their association with the Northern Atlantic Thermohaline Circulation (in Polish). Prz Geogr 88(3):295-316

Marsz A, Styszyńska A et al (2019) Course of winter temperatures in Poland in the years 1720-2015 (in Polish). Prace Geogr 2018(155):85-138

Masterson J, Richardson F (1979) Humidex, a method of quantifying human discomfort due to excessive heat and humidity, environment Canada, vol 151. Atmospheric Environment Service, Downsview, pp 1-79

Matzarakis A, Endler C (2010) Climate change and thermal bioclimate in cities: impacts and options for adaptation in Freiburg, Germany. Int J Biometeorol 54(4):479-483. https://doi.org/10.1007/s00484009-0296-2

Matzarakis A, Nastos PT (2011) Human-biometeorological assessment of heat waves in Athens. Theoret Appl Climatol 105(12):99-106. https://doi.org/10.1007/s00704-010-0379-3

Matzarakis A, Rammelberg J, Junk J (2013) Assessment of thermal bioclimate and tourism climate potential for central Europe-the example of Luxembourg. Theoret Appl Climatol 114(1-2):193202. https://doi.org/10.1007/s00704-013-0835-y

Mayer H, Höppe P (1987) Thermal comfort of man in different urban environments. Theoret Appl Climatol 38(1):43-49. https://doi.org/10.1007/BF00866252

Missenard A, Balthazard (1933) Etude physiologique et technique de la ventilation. Libraire De L'Enseignement Technique

Ndetto EL, Matzarakis A (2015) Urban atmospheric environment and human biometeorological studies in Dar es Salaam, Tanzania.
Air Qual Atmos Health 8(2):175-191. https://doi.org/10.1007/ s11869-014-0261-z

Nemeth A (2011) Changing thermal bioclimate in some Hungarian cities. Acta Climatol Chorol Univ Szeged 44(45):93-101

Nidzgorska-Lencewicz J, Mąkosza A (2013) Assessment of bioclimatic conditions within the area of Szczecin agglomeration. Meteorol Z 22(5):615-626

Niedźwiedź T (2002) Wpływ cyrkulacji atmosfery na wysokie opady w Hornsundzie (Spitsbergen) (in Polish). Probl Klimatol Polarnej 12:65-75

Novak M (2013) Use of the UTCI in the Czech Republic. Geogr Polonica 86(1):21-28

Okoniewska M, Więcław M (2013) Long-term variability of bioclimatic conditions in the second half of the 20 century at noon hours in Poland based on Universal Thermal Climate Index. J Health Sci 3(15):116-129

Rodwell MJ, Rowell DP, Folland CK (1999) Oceanic forcing of the wintertime North Atlantic Oscillation and European climate. Nature 398(6725):320. https://doi.org/10.1038/18648

Rozbicka K, Rozbicki T (2018) Variability of UTCI index in South Warsaw depending on atmospheric circulation. Theoret Appl Climatol 133(1-2):511-520. https://doi.org/10.1007/s00704-0172201-y

Siple PA, Passel CF (1945) Measurements of dry atmospheric cooling in subfreezing temperatures. Proc Am Philos Soc 89(1):177-199

Steadman RG (1979) The assessment of sultriness. Part I: a temperature-humidity index based on human physiology and clothing science. J Appl Meteorol 18(7):861-873. https://doi.org/ 10.1175/1520-0450(1979)018<0861:TAOSPI > 2.0.CO;2

Steadman RG (1984) A universal scale of apparent temperature. J Clim Appl Meteorol 23(12):1674-1687. https://doi.org/10.1175/15200450(1984)023<1674:AUSOAT>2.0.CO;2

Stephenson DB, Pavan V, Bojariu R (2000) Is the North Atlantic Oscillation a random walk? Int $\mathrm{J}$ Climatol 20(1):1-18. https://doi.org/10.1002/(SICI)1097-0088(200001)20:1<1::AIDJOC456 > 3.0.CO;2-P

Thilenius R, Dorno C (1925) Das Davoser Frigorimeter:(ein Instrument zur Dauerregistrierung der physiologischen Abkühlungsgrösse). Vieweg

Tomé AR, Miranda P, Santos F (2004) Interannual variability of the location of the main Atlantic pressure systems and the NAO index. World Resour Rev 16:357-369

Walker GT (1924) Correlations in seasonal variations of weather. I. A further study of world weather. Mem Indian Meteorol Dep 24:275-332

Wibig J (2000) The North Atlantic Oscillation and its impact on weather and climate(in Polish). Prz Geofiz 2:121-137

Yaglou C, Minaed D et al (1957) Control of heat casualties at military training centers. Arch Ind Health 16(4):302-16

Publisher's note Springer Nature remains neutral with regard to jurisdictional claims in published maps and institutional affiliations. 